PURBAWIDYA: Jurnal Penelitian dan Pengembangan Arkeologi p-ISSN: 2252-3758, e-ISSN: 2528-3618 Terakreditasi Kementerian Ristekdikti No. 21E/KPT/2018 Vol. 8 (2), November 2019, pp 135 - 157 DOI: https://doi.org/10.24164/pw.v8i2.308

\title{
SITUS PATIHMUHUR: PERANAN PADA MASANYA, NILAI PENTING, DAN STRATEGI PELESTARIANNYA
}

\author{
Patihmuhur Site: The Role, Value, and its Preservation Strategy
}

\author{
Wasita \\ Balai Arkeologi Kalimantan Selatan \\ Jalan Gotong Royong II, RT 03, RW 06, Banjarbaru, Kalimantan Selatan 70711 \\ E-mail:wasita6@yahoo.com
}

Naskah diterima: 27 September 2019 - Revisi terakhir: 22 November 2019

Disetujui terbit: 28 November 2019 - Tersedia secara online: 30 November 2019

\begin{abstract}
The purpose of this study is to determine the role of the site, its importance, and its conservation strategy. This research uses the descriptive method with inductive reasoning implementation by describing the objects and events that follows. Data collection is done by observation and is accompanied by interviews. Archaeological data is also collected through literature and historical data. Because what is needed to be revealed is the role and importance of the site, the analysis is carried out on indicators that can show this, namely the form, time, function, context, and spatial. The results showed that the Patihmuhur site was the port of Muarabahan during the Negaradaha kingdom. This site also has an essential role in trading activities involving the surrounding community and foreign nations (India and China). The role of this site has proven that Indonesia has become a part of world trade activities. Because of such high importance, this site needs to be preserved. However, due to its presence in swamps, it must be done while maintaining its natural condition, which is as long as possible flooding. In conclusion, the Patihmuhur site is proof of Indonesia's role in world trade and is pride that must be preserved.
\end{abstract}

Keywords: site role, important value, preservation

\begin{abstract}
Abstrak
Tujuan penelitian ini adalah untuk mengetahui peranan situs, nilai pentingnya, serta strategi pelestariannya. Penelitian ini menggunakan metode deskriptif dengan penalaran induktif. Pelaksanaannya dengan mendeskripsikan objek dan peristiwa-peristiwa yang menyertai. Pengumpulan data dilakukan dengan pengamatan dan dilengkapi dengan wawancara. Data arkeologi juga dikumpulkan melalui kepustakaan dan data sejarah. Oleh karena yang ingin diungkap adalah peranan dan nilai penting situs, analisisnya dilakukan terhadap indikator-indikator yang dapat menunjukkan hal tersebut, yaitu bentuk, waktu, fungsi, konteks, dan keruangan. Hasilnya menunjukkan bahwa Situs Patihmuhur merupakan pelabuhan Muarabahan pada masa kerajaan Negaradaha. Situs ini juga memiliki peranan penting dalam kegiatan perdagangan yang melibatkan masyarakat sekitar dan bangsa asing (India dan Cina). Peranan situs ini berhasil membuktikan bahwa Indonesia menjadi bagian kegiatan perdagangan dunia. Oleh karena nilai penting yang demikian tinggi, situs ini perlu dilestarikan. Namun, karena keberadaannya di lahan rawa,
\end{abstract}


pelestariannya harus dilakukan dengan tetap mempertahankan kondisi alamiahnya, yaitu selama mungkin tergenang air. Simpulan kajian ini adalah Situs Patihmuhur menjadi bukti peranan Indonesai dalam perdagangan dunia dan merupakan kebanggaan yang harus dilestarikan.

Kata kunci: peranan situs, nilai penting, pelestarian

\section{PENDAHULUAN}

Undang-undang Republik Indonesia Nomor 11 Tahun 2010 tentang Cagar Budaya, terutama Pasal 1 ayat (1) menyebutkan bahwa cagar budaya adalah warisan budaya yang bersifat kebendaan yang berupa benda cagar budaya, bangunan cagar budaya, struktur cagar budaya, situs cagar budaya, dan kawasan cagar budaya di darat dan/atau di air yang perlu dilestarikan keberadaannya karena memiliki nilai penting bagi sejarah, ilmu pengetahuan, pendidikan, agama, dan/atau kebudayaan melalui proses penetapan.

Ayat ini menegaskan bahwa situs perlu diteliti sehingga diketahui nilai pentingnya. Nilai penting itu antara lain berkaitan dengan sejarah atau berdasarkan temuannya dan dalam ruang yang sempit diketahui hal-hal yang terjadi pada situs dan bagaimana peranannya terhadap kehidupan manusia. Penelitian demikian dapat menunjukkan nilai penting sejarah situs dalam perkerangkaan sejarah Indonesia. Nilai penting itu dapat dimanfaatkan (misalnya berkaitan dengan asal-usul dan eksistensi nenek moyang) menjadi bagian identitas bangsa. Untuk sampai pada tujuan tersebut, situs arkeologi perlu dikaji secara komprehensif yang berkaitan dengan peranan dan nilai penting yang dijadikan sebagai alasan perlunya dilakukan pelestarian.

Ada beberapa penelitian yang membahas peranan situs, nilai penting, dan cara pelestariannya. Tema demikian berhasil ditemukan oleh Jajang Agus Sonjaya (2005) yang membahas lanskap warisan sejarah di Dieng, pengelolaan, dan nilai pentingnya. Tulisan ini memfokuskan pada kajian lanskap masa lalu dan penggunaannya saat ini. Penelitian ini berhasil menemukan penggunaan lanskap di kawasan percandian Dieng yang dilakukan oleh berbagai pihak, baik pemerintah, swasta, perseorangan, maupun lembaga swadaya masyarakat. Atas fakta tersebut, peneliti berusaha menemukan cara pelestarian yang tepat berdasarkan aspirasi dari pihak-pihak yang terlibat dalam pemanfaatan lanskap.

Tulisan berikutnya adalah dari Marlon Ririmasse (2007) mengenai seni cadas di Maluku. Hasil penelitiannya menunjukkan bahwa seni cadas di Maluku mempunyai nilai penting yang berkaitan dengan sejarah dan pengetahuan masa lalu. Selanjutnya, peneliti berharap karena adanya nilai penting, perlu dilakukan pelestarian.

Tulisan lain berasal dari Irfanuddin W. Marzuki (2015) mengenai potensi arkeologi di kawasan Bandara Manado. Hasil penelitiannya menunjukkan bahwa tinggalan arkeologi tersebut mempunyai nilai penting berkaitan dengan sejarah dan ilmu pengetahuan. Dengan alasan itu, perlu dilakukan pelestarian dengan cara penanganan atau perlindungan fisik dan nonfisik.

Selebihnya, ditemukan tulisan tentang kajian arkeologi yang memfokuskan pada penjelasan tentang satu aspek, yaitu kearkeologiannya, misalnya candi, fungsi, 
dan pengertiannya (Soekmono, 1995), serta peranan situs (Sutaba, 2001). Secara terpisah kita juga sering menemukan tematema tulisan yang berkaitan dengan nilai penting, misalnya nilai penting bangunan megalitik untuk kepentingan religi dan sosial pada zamannya (Atmosudiro, 1981), fokus pada strategi pelestariannya saja, yaitu dengan menyusun kebijakan umum, menentukan prioritas, melakukan langkah hukum, ilmiah, teknis, ataupun administrasi, serta membentuk pusatpusat kajian ilmiah lokal untuk pelatihan dalam perlindungan (Zain, 2014), dan ada yang menggabungkan keduanya dalam satu tema tulisan.

Berkaitan dengan pembahasan dua tema itu, contohnya ialah mengenai nilai penting situs dan strategi pelestariannya. Dalam tema penelitian yang demikian ini Yudi Suhartono (2008) berhasil membuat pemintakan/zonasi kawasan Borobudur dalam bentuk peta struktur dan peta fungsi ruang yang merupakan penjelasan fungsi setiap sumber daya arkeologi. Peta struktur dan peta fungsi ruang, kemudian digabungkan untuk dilihat kondisi keruangannya guna mengetahui pengendalian pemanfaatan ruang di lingkungan Candi Borobudur, Candi Mendut, dan Candi Pawon. Langkah selanjutnya adalah membuat strategi pelestarian dengan pendokumentasian sumber daya arkeologi.

Berdasarkan paparan di atas, diketahui bahwa ketiganya merupakan satu kesatuan yang utuh, penting, dan diperlukan dalam kerja arkeologi. Akan tetapi, tampaknya masih banyak peneliti bekerja secara terkotak-kotak. Sejauh ini peneliti masih lebih banyak memfokuskan pada penjelasan tentang hal-hal yang berkaitan dengan kejadian masa lalu di
situs.Tidak dimungkiri bahwa ini penting, tetapi sebaiknya tidak hanya berhenti di situ sebab jika hanya sampai di situ, bisa jadi kerja pelestarian dan pemanfaatan relevansinya kurang dengan kegiatan penelitian. Kemungkinan terjadinya kekurangrelevanan tersebut karena tidak dilakukan kajian menyeluruh yang berkaitan dengan penjelasan peranan situs pada masanya, nilai penting situs pada masa lalu yang dapat diterapkan pada masa kini, dan upaya pelestariannya yang tepat.

Dengan pemikiran yang demikian, peneliti berupaya membahas ketiganya pada Situs Patihmuhur karena menurut peneliti situs tersebut mempunyai potensi berkaitan dengan pembahasan tiga tema di atas dan hasilnya dapat diimplementasikan. Dorongan inilah yang mengantarkan peneliti untuk menyumbangkan pemikirannya. Oleh karena itu, permasalahan yang ingin dipecahkan dalam penelitian ini adalah (1) Bagaimana peranan Situs Patihmuhur pada masanya?; (2) Apa nilai penting Situs Patihmuhur pada saat ini?; (3) Bagaimana strategi pelestarian Situs Patihmuhur sesuai dengan kondisinya?

Penelitian ini ditujukan untuk mengetahui peranan situs pada masanya, nilai penting yang dapat dimanfaatkan, dan mengetahui strategi pelestarian yang tepat sesuai dengan kondisinya.

Membahas mengenai peranan, menurut Soejono Soekanto, dalam buku yang berjudul Sosiologi Suatu Pengantar dijelaskan pengertian istilah tersebut yang merupakan aspek dinamis kedudukan (status). Peneliti ini memang lebih menekankan bahwa aspek dinamis itu disematkan pada orang sehingga dinyatakan bahwa apabila seseorang 
melakukan hak dan kewajibannya sesuai dengan kedudukannya, dia menjalankan suatu peranan (Soekanto \& Sulistyowati, 2012). Sementara itu, dalam tulisan ini istilah peranaan digunakan untuk benda atau objek, yaitu tinggalan arkeologi. Oleh karena adanya peranan yang diemban oleh orang atau pun objek, di situ ada nilai-nilai.

Penulis bermaksud mengungkap nilainilai yang ada pada situs karena diyakini bahwa nilai itu disematkan setelah memainkan peranan penting dalam suatu kegiatan. Penggunaan istilah nilai untuk benda terdorong oleh pernyataan William D. Lipe (2009) yang mengatakan bahwa "...the starting point for management is to consider a variety of resource values when making choices about which sites to protect and how to manage them." (...titik awal untuk manajemen adalah mempertimbangkan berbagai nilai sumber daya ketika membuat pilihan tentang situs yang akan dilindungi dan bagaimana cara mengelolanya). Peneliti ini menyebutkan bahwa nilai sumber daya arkeologi ditentukan atau bergantung pada konteks atau kerangka referensi yang dikembangkan secara sosial dan historis. Nilai itu berkaitan dengan kebermaknaan yang meliputi nilai warisan budaya, pelestarian, penelitian, estetika, pendidikan, dan ekonomi.

Jika memperhatikan pandangan Lipe, ada dua kategori, yaitu nilai penting dan pemanfaatannya. Nilai penting situs diperoleh dari hasil penelitian, misalnya tentang peranan situs pada masanya. Berkaitan dengan kerangka teoretis yang demikian, sebenarnya peranan tidak dapat diungkap secara langsung. Untuk itu, yang harus dilakukan adalah mengamati indikator-indikator yang dapat menjelaskan peranan.
Berdasarkan serangkaian analisis tersebut, munculkan ide peranan situs bagi masyarakat yang hidup di sekitar situs pada saat itu. Peranan situs yang menjadi pengetahuan masa lalu memungkinkan memiliki kebermaknaan pada masyarakat yang hidup saat ini. Bahkan, mungkin pengetahuan mengenai konstruksi penyangga bangunan di lahan rawa masih relevan untuk diterapkan saat ini.

Kebermaknaan itu merupakan bagian dari nilai penting situs yang perlu dilestarikan. Selanjutnya, karena lokasi situs berada di tanah rawa, kondisinya spesifik dan memerlukan kajian agar diketahui cara yang tepat dalam melestarikannya. Hal-hal yang akan dikerjakan dalam penelitian ini, seperti yang disebutkan di atas, dapat digambarkan dalam kerangka teoretis atau alur pemikiran (lihat Gambar 1).

Penelitian ini menggunakan metode deskriptif dengan penalaran induktif. Pelaksanaannya adalah dengan mendeskripsikan objek penelitian, gejala, dan peristiwa yang terjadi. Penelitian deskriptif berusaha memusatkan perhatian kepada masalah-masalah aktual sebagaimana adanya pada saat penelitian berlangsung. Dengan demikian, penelitian deskriptif berusaha mendeskripsikan suatu gejala, peristiwa, dan kejadian, sebagaimana adanya pada saat penelitian berlangsung (Juliansyah, 2011). Pendeskripsian itu dilakukan untuk membuat gambaran secara sistematis mengenai fakta-fakta, sifat-sifat, serta hubungan antarfenomena yang diteliti (Arikunto, 2002).

Dalam operasionalnya, pengumpulan data dilakukan melalui observasi atau pengamatan, wawancara, dan studi 
pustaka. Pengamatan dimaksudkan untuk mendapatkan data mengenai apa yang terjadi atau yang ada, misalnya tentang tiang-tiang dan kondisinya di lapangan, di mana ditemukan, dan dalam keadaan yang seperti apa. Sementara itu, wawancara dimaksudkan untuk mengetahui gambaran keadaan di lapangan yang berkaitan dengan situs dan perlakuannya. Hal itu dimaksudkan untuk mengetahui apa saja yang telah dilakukan dan dampaknya. Wawancara juga dimaksudkan untuk mengetahui kondisi situs dalam kesehariannya dan bagaimana pula kondisinya pada sepanjang tahun. Pengetahuan ini dapat dimanfaatkan untuk menduga kemungkinan dampak dari kondisi tersebut terhadap situs atau justru manfaat apa yang didapat oleh situs dari kondisi tersebut.

Sementara itu, studi pustaka dimaksudkan untuk mengetahui situs menurut para peneliti berdasarkan hasil kajian sejarah ataupun arkeologi yang dapat mendukung penelitian ini. Penelusuran data pustaka dimaksud agar dapat diperoleh gambaran situs dari pandangan para ahli. Berkaitan dengan tulisan, juga dimanfaatkan data sejarah, yaitu Hikayat Banjar. Data ini diharapkan dapat menunjukkan hal-hal yang berkaitan dengan situs menurut dokumen sejarah.

Seperti yang disebutkan sebelumnya bahwa peranan situs tidak dapat langsung diungkap sehingga yang harus dilakukan adalah meneliti indikator-indikatornya. Indikator itu diperoleh dari temuan di situs yang dapat menginformasikan halhal yang berkaitan dengan peranan situs. Indikator itu meliputi bentuk, waktu, fungsi, konteks, dan ruang. Oleh karena itu, yang dilakukan dalam penelitian ini berupa analisis bentuk, waktu, fungsi, konteks, dan keruangan.
Analisis bentuk dimaksudkan untuk mengetahui bentuk apa saja yang diperoleh di situs. Analisis fungsi diketahui dari temuan dan hal-hal yang ada pada temuan tersebut, misalnya adalah temuan kayu utuh yang ditancapkan berjajar memberikan indikasi fungsi apa. Analisis konteks diungkap dari konteks temuan terhadap temuan yang lain dan juga alam di sekitarnya, misalnya adalah temuan tiang yang berjajar banyak dan ditemukan di dekat sungai mengindikasikan konteks apa yang pernah terjadi pada keduanya. Sementara itu, dari analisis ruang dicoba diketahui keberadaan temuan di ruangruang, misalnya temuan di tepi sungai dan di daratan.

Terakhir adalah upaya mengungkap waktu keberlangsungan situs, dari situ diharapkan dapat diketahui rentang waktu, kapan temuan-temuan arkeologi tersebut digunakan oleh manusia dalam menjalani aktivitas kehidupan. Aspek waktu ini pula yang dapat menempatkan temuan dan Situs Patihmuhur dalam posisi yang relevan dengan perkerangkaan sejarah di Kalimantan Selatan.

\section{HASIL DAN PEMBAHASAN}

\section{Data Arkeologi}

Secara administratif, Situs Patihmuhur berada di desa Patihmuhur, Kecamatan Anjir Muara, Kabupaten Barito Kuala, Kalimantan Selatan. Lokasi situs ini berada di tepi sungai Barito, tepatnya di sisi barat sungai. Titik koordinat situs ini berada pada -3.174046 atau $3^{\circ} .10^{\prime} .26 .566^{\prime \prime}$ Lintang Selatan dan 114.567236 atau $114^{\circ} .34^{\prime} .2 .050^{\prime \prime}$ Bujur Timur.

Temuan di situs ini berasal dari hasil penggalian dan survei. Dalam kuantitas yang tidak terlalu banyak, temuan hasil 
penggalian berupa pecahan tembikar, alat kayu, tusuk kayu, tatal kayu, fragmen batu rijang, batu oker (pewarna), fragmen tulang, fosil daun, dan fragmen tulang. Dari kegiatan survei ditemukan tiang-tiang kayu utuh yang jumlahnya cukup banyak. Tiang-tiang itu ada yang ditemukan terpisah di tepi Sungai Barito, mengelompok di daratan dekat sungai, dan ada yang menyambung dari kelompok tiang-tiang di daratan yang berjajar ke arah belakang atau menjauhi sungai. Ada juga yang mengelompok di bagian belakang atau letaknya $2 \mathrm{~km}$ dari Sungai Barito, yaitu di persawahan (Wasita, 2007).

Temuan tiang-tiang di tepi sungai Barito ada tujuh buah.Tiga temuan tiang mengelompok di tepi sungai di depan pelabuhan sisi kiri (berdiri menghadap pelabuhan), satu tiang berada persis di depan pelabuhan, dan tiga tiang berada di sisi kanan pelabuhan yang posisinya agak jauh, yaitu pada pertemuan Sungai Patihmuhur dan Sungai Barito. Tiangtiang tersebut tidak menunjukkan adanya pengerjaan di bagian puncak ataupun sedikit di bawah puncaknya.

Sementara itu, temuan tiang-tiang mengelompok yang berada di daratan di dekat Sungai Barito keberadaannya teratur dalam interval $1-2 \times 4$ meter. Ting-tiang dengan interval 1 meter berjajar membujur arah utara-selatan (sejajar dengan Sungai Barito). Jajaran tiang dengan interval ini ada pada setiap kelompok tiang paling selatan dan utara. Sementara itu, di bagian tengah, setiap intervalnya adalah 2 meter. Sementara itu, interval 4 meter adalah jarak antara tiang yang memanjang arah timur-barat (lihat Gambar 2).

Dalam penelitian ini dilakukan penggalian pada salah satu titik temuan tiang yang berdampingan (tiang dobel).
Kedua tiang tersebut berjarak kurang lebih lima puluh sentimeter. Setelah dilakukan penggalian, diketahui bahwa pada kedalaman sekitar satu meter dari permukaan tanah, pada salah satu tiang tersebut, terdapat lubang yang berbentuk persegi empat yang tembus dari sisi satu ke sisi lainnya. Pada lubang tersebut diletakkan kayu hingga tembus kurang lebih sepanjang satu meter lebih dan sisi satunya yang kurang dari satu meter (lihat Gambar 3a-b).

Mendekati ujung balok kayu tersebut (sisi kiri/barat tiang), di bawahnya diletakkan batang kayu utuh dalam posisi horizontal (kalang) yang membujur utara-selatan.Selanjutnya, kanan dan kiri kalang ditahan dengan patok dari bahan batang kayu gelam. Tampaknya, hal ini dimaksudkan untuk menahan kalang agar tetap stabil. Kestabilan juga diupayakan dengan menakik kalang untuk tempat pijakan sunduk. Kestabilan keduanya akan berdampak pada kestabilan tiang utama yang tampak di atas permukaan tanah.

Penelitian ini juga berhasil membuktikan adanya kalang di sisi yang satunya.Temuan yang demikian ini kemudian dicocokkan dengan para pekerja yang sebelumnya melakukan pencabutan batang kayu dan mereka menyatakan bahwa kalang ada di kanan dan kiri tiang serta ada hampir di setiap tiang.

Informasi ini menunjukkan bahwa tiang-tiang itu dikaitkan dengan kalang untuk menstabilkan tiang. Jadi, semua itu merupakan konstruksi yang disengaja untuk menciptakan kestabilan tiang-tiang yang dimaksudkan untuk menyangga bangunan di atasnya. Jika titik-titik tiang itu meliputi luasan 20x8 meter, sisi panjang $(20 \mathrm{~m})$ menjauhi sungai atau arah timur-barat, lebar $(8 \mathrm{~m})$ arah utara-selatan, 
tampaknya konstruksi di atas tiang-tiang tersebut luasannya juga kurang lebih sama.

Selanjutnya, di bagian belakang jajaran tiang yang membentuk ukuran 20x8 meter (pojok belakang sisi selatan, arah menjauhi Sungai Barito), terdapat jajaran dua tiang (kanan-kiri jarak 1 meter dan berinterval sekitar 3 meter). Jajaran tiang itu ke arah belakang atau menjauhi Sungai Barito. Temuan ini awalnya berada pada arah 260 derajat, tetapi setelah di titik interval sekitar 9 meter, posisinya bergeser sedikit ke arah utara atau $>260$ derajat. Temuan berikutnya juga agak bergeser ke utara dan hanya sebagian kecil yang bergeser ke arah selatan atau $<260$ derajat dari titik terakhir.Walaupun tidak selalu ditemukan di setiap interval 3 meter dan tidak selalu lengkap ada tiang di sisi kanan dan kiri, temuan tiang masih ada hingga jarak sekitar 400 meter. Setelah jarak 400 meter, arealnya berupa hamparan yang agak membukit dan ditumbuhi banyak semak belukar yang rapat. Areal ini tidak disurvei.

Tim kemudian berjalan memutar, mengelilingi bukit untuk menuju ke titik atau arah $260^{\circ}$ dari titik temuan terakhir (sebelum bukit yang bersemak-semak). Akhirnya, pada jarak sekitar 700 meter dari titik temuan terakhir, ditemukan tiang tunggal. Maksudnya adalah tiang itu hanya satu, baik di sisi kanan maupun kirinya tidak ditemukan tiang. Temuan ini tidak menunjukkan posisi yang lurus dengan 260 derajat dari temuan tiang terakhir.

Setelah jarak tersebut tidak ditemukan lagi tiang, baik tunggal maupun dobel atau kanan dan kiri. Hanya saja pada jarak sekitar $2 \mathrm{~km}$ dari tepi Sungai Barito, ditemukan jajaran kayu dengan interval sekitar 7,5 meter ke kanan dan kiri sehingga membentuk areal persegi empat, seperti temuan yang ada di tepi Sungai Barito. Temuan yang terakhir ini berada di areal persawahan warga.

Berdasarkan deskripsi, diduga bahwa temuan tiang di tepi Sungai Barito merupakan penambat kapal, tiang-tiang di daratan dekat sungai merupakan penyangga bangunan (pelabuhan). Sementara itu, tiang-tiang yang berjajar dua yang menjauh ke arah belakang/ menjauhi sungai adalah tiang yang menjadi penopang titian. Selanjutnya, tiang-tiang yang membentuk areal persegi empat di bagian belakang, yaitu di areal persawahan, juga merupakan tiang-tiang penyangga bangunan di atasnya (rumah).

\section{Data Literatur dan Sejarah}

Dalam penelitian ini dibedakan data literatur dan sejarah. Data literatur berupa tulisan sejarah yang dihasilkan oleh ilmuwan sekarang dengan kajian masa lalu, yang berkaitan dengan tema penelitian, yaitu masa sejarah yang berkaitan dengan temuan arkeologi di Situs Patihmuhur, Kabupaten Barito Kuala.Sementara itu, yang disebut data sejarah berasal dari data tulisan masa lalu yang dihasilkan oleh pelaku sejarah pada masanya, misalnya Hikayat Banjar.

Data yang berasal dari analisis kesejarahan di kawasan situs ini diperoleh melalui pustaka, yaitu tulisan para sejarawan ataupun arkeolog yang menekuni arkeologi sejarah.Tulisantulisan yang sejauh ini berhasil didapatkan berupa penelitian yang tidak difokuskan membahas tiang-tiang kayu di Patihmuhur. Dalam penelitian bersama koleganya, Ira Mentayani dan Dila Nadya Andini (2007) dan penelitiannya sendiri (Mentayani, 2008b) diperoleh hasil bahwa Kerajaan 
Negaradaha pada permulaan abad ke-16 digambarkan penuh dengan perseteruan antara Pangeran Samudera sebagai pewaris sah kerajaan dengan pamannya yang bernama Pangeran Temenggung yang berhasil menguasai kerajaan. Dalam tulisannya yang lain, Ira Mentayani (2008a) juga menyatakan bahwa terjadi konflik antara masyarakat Negaradaha pedalaman dan pesisir.

Hasil penelitian itu menguatkan bahwa ada wilayah permukiman masyarakat Kerajaan Negaradaha di pedalaman dan sebagian yang lain di pesisir. Dugaan permukiman di pedalaman juga ditunjukkan oleh hasil penelitian arkeologi. Sunarningsih (2013) yang melakukan penelitian arkeologi di daerah Penggandingan di Kabupaten Tapin, Kalimantan Selatan, menyatakan bahwa kawasan situs tersebut pernah menjadi wilayah kekuasaan kerajaan pra-Islam di Kalimantan Selatan, yaitu Kerajaan Negaradaha. Namun, peneliti ini menyebutkan bahwa asumsi itu masih perlu dibuktikan.Di bagian akhir tulisannya, peneliti ini menyarankan bahwa areal permukiman dan data arkeologi terkait Kerajaan Negaradaha perlu dicari di sepanjang tepian Sungai Negara yang merupakan anak Sungai Barito.

Di sisi lain, ada peneliti sejarah yang menyatakan bahwa Kerajaan Negaradaha memiliki Ibu Kota di Muarabahan. Kota tersebut juga merupakan tempat keberadaan pelabuhan Muarabahan. Peneliti ini juga menceritakan bahwa Pangeran Samudera mendayung perahu dari Kerajaan Negaradaha hingga ke pelabuhan Muarabahan (Idwar, 1958). Wilayah ini sekarang berada di Marabahan, Kabupaten Barito Kuala, Kalimantan Selatan.
Sementara itu, Hikayat Banjar merupakan data tulisan yang berasal dari masa lalu yang antara lain menceritakan Kerajaan Negaradaha dan tokoh-tokoh pada masa itu. Sebagian isi hikayat itu menceritakan situasi kerajaan pada masa pemerintahan Pangeran Temenggung. Saat itu kerajaan digambarkan berada dalam situasi yang kurang kondusif untuk keamanan sang putra mahkota, Raden Samudera. Atas saran beberapa pembesar kerajaan yang berpihak kepadanya, Raden Samudera dimohon pergi meninggalkan kerajaan. Pangeran yang masih merupakan seorang anak yang belum dewasa dibekali perahu oleh para pengikutnya dan disarankan untuk mendayung perahunya ke arah hilir dan mencari tempat berlindung di suatu tempat yang dianggap aman. Akhirnya, putra mahkota itu sampai ke suatu pelabuhan yang ramai (diduga Pelabuhan Muarabahan). Kemudian, ia sembunyi di seberang pelabuhan dan tinggal di sebuah desa yang bernama Belandean (Ras, 1968). Nama Desa Bilandean itu sekarang masih ada. Lokasinya sekarang berada di seberang temuan tiang-tiang kayu ulin di Patihmuhur (lihat Gambar 4).

\section{Data Wawancara}

Berkaitan dengan kondisi lingkungan di sekitar situs, diperoleh informasi dari masyarakat bahwa temuan yang di sungai (tepi sungai) terendam air sepanjang tahun.Tiang-tiang di dekat sungai berada dalam areal yang terendam air selama kurang lebih delapan bulan per tahun. Pada puncak musim kemarau di lokasi ini biasanya tidak ada genangan, tetapi tanah masih relatif basah. Sementara itu, pada temuan tiang-tiang yang memanjang berjajar dua yang ditemukan hingga jarak 
sekitar 400-an meter ke arah menjauhi Sungai Barito, ada sebagian tiang-tiang yang terendam air tidak terlalu lama. Hal ini disebabkan sebagian tempat tersebut, terutama yang mendekati areal yang membukit, merupakan lokasi yang agak tinggi. Biasanya di areal yang agak tinggi tersebut, jika intensitas hujan mulai berkurang, tidak ada lagi genangan air dan pada musim kemarau menjadi kering. Lokasi temuan tiang-tiang di persawahan, pada musim kemarau, biasanya tanahnya kering.

Berdasarkan hasil wawancara dengan masyarakat, diketahui bahwa umumnya mereka mengetahui adanya tunggul (pokok pohon yang ditebang, tetapi sebenarnya itu adalah tiang) dan persebarannya. Walaupun masyarakat mengetahui keberadaan tiang-tiang kayu yang berupa kayu utuh, mereka tidak mengusik kayu itu secara serius. Maksudnya adalah mereka tidak mengambil kayu itu untuk kepentingan pribadinya. Walaupun demikian, ada juga informan yang mengaku pernah mencoba mencabut tiang, yang umumnya sebagian tiang berada di atas tanah sekitar 20 hingga $30 \mathrm{~cm}$, tetapi tidak berhasil. Setelah kejadian itu yang bersangkutan tidak pernah lagi mencoba mencabut tiang-tiang kayu utuh yang ada di kampungnya. Atas kejadian tersebut pada saat itu masyarakat menganggap bahwa akar tunggul itu besar dan kuat sehingga sulit untuk digoyang saat hendak dicabut.

Sekarang ini umumnya masyarakat Desa Patihmuhur menyesuaikan dengan tiang-tiang tersebut. Maksudnya adalah jika faktanya tiang-tiang tersebut ada di lahan yang digarap, akan tetap dibiarkan keberadaannya karena mereka memang tidak dapat mencabutnya. Biasanya yang dilakukan adalah memangkas atau hanya meratakan ujung kayu tersebut agar tidak membahayakan ketika mereka sedang beraktivitas di sawah. Bahkan, ada pula sebagian masyarakat yang memotong ujung kayu itu di bagian yang terpendam. Hal ini dilakukan agar tiang kayu gelondongan tersebut tidak membahayakan ketika mereka beraktivitas dan juga tidak mengganggu tanaman. Pemotongan yang demikian ini kurang lebih pada kedalaman 20 hingga $30 \mathrm{~cm}$ dari atas permukaan tanah. Oleh karena itu, tiang-tiang yang dipotong seperti ini yang ada di persawahan, masih bisa ditemukan karena bantuan informasi dari masyarakat.

Menurut informan, interaksi masyarakat dengan tiang-tiang itu berubah setelah kedatangan orang dari Banjarmasin. Kedatangan orang tersebut karena mendapatkan informasi tentang tunggul-tunggul kayu di sebuah lahan. Setelah yang bersangkutan melihat langsung, ia berniat membeli lahan tersebut. Setelah pemiliknya ditemui dan terjadi kesepakatan di antara keduanya, transaksi pun dilakukan.

Selanjutnya, sebagai pebisnis di bidang perkayuan, nalurinya terdorong untuk segera memanfaatkan tunggul-tunggul kayu tersebut. Kemudian, dikerahkan anak buahnya untuk mencabut tunggul-tunggul itu. Alat yang digunakan adalah crane, yaitu alat berat yang biasanya digunakan untuk mengangkat atau memindahkan material (Gambar 5).

Setelah ada yang tercabut, masyarakat baru tahu bahwa panjang tiang itu ratarata 4 meter. Tiang ditancapkan dalam posisi terbalik, yaitu bagian pangkal kayu berada di atas dan bagian ujung kayu diposisikan di bagian bawah. Ujung kayu yang berada di posisi bawah dibentuk 
lancip.Tampaknya ini dimaksudkan untuk mempermudah dilakukannya dorongan ketika tiang itu ditancapkan.

Masyarakat juga baru mengetahui bahwa sebagian tiang ada yang dilubangi dengan bentuk persegi empat pada kedalaman sekitar satu meter dari atas permukaan tanah. Kemudian, pada lubang yang tembus tersebut dipasang balok kayu panjang. Bahkan, umumnya masyarakat tidak menduga bahwa tunggul-tunggul itu jumlahnya demikian banyak. Karena ternyata, kayu itu tidak hanya ada dalam posisi vertikal, tetapi ada juga yang berada dalam posisi horizontal. Kayu gelondongan yang dalam posisi horizontal itu tidak kelihatan karena letaknya sekitar satu meter di bawah permukaan tanah.

Setelah adanya pencabutan tiang-tiang tersebut, informasinya tersebar luas di masyarakat. Media massa, cetak ataupun elektronik, ada yang turut memberitakan. Atas kejadian itu aparat keamanan pun turun ke lapangan. Selanjutnya, dengan alasan pemindahan kayu ulin harus ada izin dan ternyata pihak yang berusaha membawa kayu tersebut belum memiliki izin, polisi menghentikan aktivitas pencabutan kayu-kayu tersebut. Dalam situasi yang demikian ini pihak arkeologi datang untuk melakukan penelitian.

\section{Peranan Situs Patihmuhur}

Berdasarkan data literatur dan sejarah diketahui bahwa Muarabahan adalah nama pelabuhan. Selanjutnya, perlu dibuktikan lokasi yang disebut Muarabahan adalah situs Patihmuhur sekarang. Upaya untuk membuktikan dilakukan dengan melihat bentuk dan kesesuaian waktu kehadiran objek dalam periode sejarah Kerajaan Negaradaha.
Melalui analisis bentuk, diketahui bahwa temuan arkeologi di Situs Patihmuhur berupa artefaktual lepas, tiang-tiang kayu utuh tidak teratur di tepi sungai Barito, berjajar dengan interval tiga meter dan memanjang hingga jarak hampir 1.100 meter dari jajaran tiang 20x8 meter, membentuk pola persegi empat yang ditemukan di dekat sungai dan persawahan.

Analisis bentuk dari temuan artefak lepas yang berupa pecahan tembikar, alat kayu, tusuk kayu, tatal kayu, fragmen batu rijang, batu oker (pewarna), fragmen tulang, fosil daun, dan fragmen tulang, dengan kualitas dan kuantitas yang terbatas, tidak mudah untuk dihubungkan dengan keinginan mengetahui bentuk dan fungsinya.

Temuan tiang-tiang di tepi sungai ditempatkan dalam pola acak. Sulit diketahui bentuk yang diinginkan dari pola yang ada. Sementara itu, temuan tiang berjajar yang membentuk pola segi empat ada dua temuan. Tiang berjajar membentuk pola persegi empat yang berada di tepi Sungai Barito, seperti yang disebutkan di depan, berukuran 20x8 meter. Tampaknya jajaran tiang-tiang yang membentuk pola persegi empat itu berfungsi untuk menyangga sesuatu atau bangunan. Namun, jejak-jejak penggunaannya tidak diketahui karena umumnya bagian tiang telah aus.

Berkaitan dengan kualitas temuan yang demikian, upaya mengetahui bentuk temuan jajaran tiang di tepi sungai, dicoba diungkap temuan tiang-tiang dalam mendukung suatu bentuk bangunan tertentu.Tiang-tiang di Situs Patihmuhur berdiri dengan cara berjajar dalam interval 4 meter memanjang arah timur-barat dan 
interval 1 dan 2 meter arah utara-selatan. Jajaran tiang-tiang dalam enam baris arah timur-barat dan empat baris (termasuk yang dobel) arah utara-selatan itu akhirnya membentuk pola persegi empat panjang. Dengan bentuk yang demikian ini dapat diasumsikan bahwa ada sesuatu yang lebar yang akan disangga oleh tiang-tiang tersebut.

Namun, untuk mengetahui lebih banyak apa saja yang ada di atas tiang, tidaklah mudah. Ujung atau puncak tiangtiang itu umumnya telah aus sehingga tidak terlihat jejak-jejak penggunaannya, misalnya disambungkan dengan kayu lain. Oleh karena itu, untuk mengetahui bentuk tiang secara utuh, perlu diungkap melalui tiang kayu yang ada di dalam tanah. Hasil penelitian menunjukkan bahwa kurang lebih satu meter dari atas permukaan tanah, pada sebagian tiang-tiang, terdapat lubang seperti segi empat. Pada lubang tersebut kemudian diletakkan balok kayu panjang yang melintang menembus tiang (sunduk).

Di bawah kedua ujung balok kayu (sunduk) diletakkan kayu gelondongan atau utuh dalam posisi horizontal atau rebah (kalang).Berdasarkan penuturan pekerja yang mencabut tiang-tiang, diketahui bahwa kalang itu membujur utara-selatan. Jumlah kalang ada dua buah, yaitu di bagian kanan dan kiri tiang. Hal itu dimaksudkan untuk menyangga tiang agar tetap stabil. Selain dari informan, juga diperoleh bukti dari hasil penelitian bahwa di samping kanan dan kiri kalang dipasang patok yang berasal dari kayu gelam. Tampaknya, patok itu berfungsi untuk menahan kayu gelondongan dalam posisi horizontal agar tidak bergerak ke kanan dan ke kiri (lihat Gambar 6).
Berdasarkan pendeskripsian di atas, dari aspek bentuk diketahui bahwa di bagian yang terpendam di tanah rawa dibuatkan kaityang disebutkalang-sunduk. Hasil penelitian mahasiswa Program Studi Magister Teknik Sipil, Universitas Lambung Mangkurat menyebutkan bahwa tiang dengan konstruksi kalang-sunduk dikenal juga pada bangunan rumah tradisional masyarakat Banjar (Afni, 2017) yang biasanya didirikan di lahan rawa. Dengan demikian, bentuk-bentuk konstruksi tiang di Situs Patihmuhur dimaksudkan sebagai bagian bangunan yang kukuh. Konstruksi bangunan yang kukuh dan diciptakan kestabilan yang baik tampaknya berkaitan dengan fungsi untuk menopang sesuatu yang berat, mungkin papan lantai dermaga yang luasnya $20 x 8$ meter persegi.

Dugaan ini dikuatkan oleh analisis keruangan terhadap temuan tujuh tiang di tepi Sungai Barito. Ketujuh tiang itu mengindikasikan fungsi yang berbeda dengan yang di daratan. Tiang di sungai pada ukuran satu meter di bawah puncaknya tidak berada di dalam tanah, tetapi berada di dalam air. Oleh karena itu, tidak diperlukan kalang ataupun sunduk untuk memperkukuh keberadaan tiang di dalam air. Di samping itu, perwujudan tiang yang demikian ini menunjukkan bahwa tiang tersebut berfungsi secara tunggal.

Temuan tiang pada ruang yang demikian ini menegaskan fungsi di perairan. Secara keruangan kedua temuan itu juga saling menguatkan, yaitu temuan tiang di daratan sebagai penyangga lantai dermaga dan tiang di sungai sebagai penambat kapal. Mengapa tiang yang diduga sebagai penambat kapal, pada saat ini posisinya tidak persis di pinggiran sungai Barito? 
Tampaknya hal ini dapat dijelaskan dengan terjadinya perubahan pada morfologi sungai. Istilah morfologi sungai digunakan untuk membahas halhal yang berkaitan dengan aliran serta sifatnya, kemiringan saluran, dan daya tampung. Pengaruh morfologi sungai ini akan terlihat pada ukuran dan bentuk sungai karena kondisi hidraulik dari aliran (Junaidi, 2014). Berkaitan dengan struktur geologi di suatu daerah, aliran air (pada sungai) dipengaruhi oleh struktur geologi, seperti antiklin, sinklin, dan sesar yang memotong sungai. Sesar merupakan struktur geologi yang pengaruhnya paling signifikan terhadap munculnya bentuk sinusitas atau tingkat kelengkungan sungai (Ramadhan, Difa Masti, Pamungkas, \& Setianto, 2017).

Dari penelitian geologi di Kecamatan Barambai dan sekitarnya diketahui bahwa tidak terdapat struktur geologi seperti siklin dan antiklin (Tjahjono, 2007). Lokasi Kecamatan Barambai berada di sebelah utara Kecamatan Anjir Muara yang salah satu desanya adalah Patihmuhur yang merupakan lokus penelitian ini. Sementara itu, menurut peta geologi Lembar Banjarmasin 1712 skala 1:250.000 diketahui bahwa material di Patihmuhur merupakan endapan aluvium yang berupa kerikil, pasir, lanau, lempung, dan lumpur.

Jika memperhatikan struktur geologi dan materialnya, yang memungkinkan memengaruhi morfologi Sungai Barito di lokasi penelitian adalah erosi. Bukti terjadinya erosi adalah adanya endapan sedimen. Hasil penelitian sedimen di delta Barito menunjukkan bahwa di muara sungai itu terdapat endapan material hasil kikisan di hulu (Arisanty, 2014) atau paling tidak areal yang lebih hulu daripada delta. Kikisan itu antara lain berasal dari tebing dan dasar sungai.

Tebing atau tepian sungai akan lebih mudah mengalami erosi jika di bantarannya hanya terdapat sedikit tegakan (sebaran jumlah pohon per satuan luas yang berdasarkan kelas diameternya) (Pertiwi, Dharmono, \& Amintarti, 2017) atau diakibatkan oleh hempasan gelombang yang timbul karena adanya lalu lintas pelayaran (Harto, 2015; Novitasari, 2016). Sebab yang terakhir tersebut tidak dimungkiri oleh Pokja Sanitasi Kabupaten Barito Kuala yang menyebutkan bahwa salah satu permasalahan sanitasi di kawasan tepian Sungai Barito adalah erosi yang disebabkan oleh gelombang air yang muncul setelah kapal melintas. Di sisi lain, jika diperhatikan kondisi tepian sungai Barito di areal dekat situs Patihmuhur, tidak banyak pohon besar yang dimanfaatkan untuk membantu menahan terjadinya erosi.

Berkaitan dengan analisis keruangan, temuan lain yang perlu disebut adalah jajaran tiang-tiang di kanan dan kiri lantai pelabuhan. Jajaran tiang-tiang tersebut berada dalam kondisi yang rapat, sejajar dengan tiang-tiang paling tepi, baik di kanan dan kiri maupun membujur ke arah timur-barat, dengan panjang jajaran tiang sekitar empat meter. Tiang-tiang yang disusun rapat tersebut kemungkinan digunakan untuk menahan hempasan air agar pada areal pelabuhan tidak terjadi erosi.

Sementara itu, analisis konteks beberapa sifat kelompok temuan tiang, baik di daratan maupun sungai, juga menguatkan dugaan temuan itu sebagai pelabuhan. Konteks kelompok temuan tiang di daratan yang membentuk pola persegi empat dan jajaran tiang yang 
memanjang juga mendukung fungsi pelabuhan. Fungsi jajaran tiang itu sebagai jalan dari dan menuju pelabuhan dan sebaliknya ke areal permukiman.

Penelusuran ke arah belakang pada jarak sekitar dua $\mathrm{km}$ dari tepi sungai adalah ditemukan tiang-tiang yang juga membentuk pola persegi empat yang luasnya $7,5 \times 7,5$ meter. Sama halnya dengan yang ada di tepi sungai, tiangtiang itu diduga sebagai penyangga sesuatu (bangunan) di atasnya.Temuantemuan tersebut secara kontekstual, baik yang di tepi sungai maupun yang ada di persawahan, dapat dikatakan sebagai satu kesatuan dan saling mendukung fungsi pelabuhan. Jalan merupakan pendukung untuk jalur transportasi dari pelabuhan menuju ke arah belakang (barangkali areal permukiman). Lokasi yang diduga sebagai areal permukiman dikuatkan oleh temuan tiang-tiang yang ada di areal persawahan sekarang, yang jaraknya dua $\mathrm{km}$ dari tepi sungai Barito.

Sementara itu, umur situs berkaitan dengan upaya menemukan waktu keberlangsungan situs dalam suatu babakan sejarah. Untuk analisis umur, digunakan metode radiokarbon yang dilakukan oleh Pusat Penelitian Pengembangan Geologi Bandung. Sampel yang dianalisis adalah kayu gelam yang ditemukan dan pada kedalaman sekitar 130 hingga $140 \mathrm{~cm}$ di bawah permukaan tanah. Kayu gelam itu difungsikan sebagai patok untuk menahan kalang.

Pemilihan sampel pada kayu gelam dilakukan karena diyakini bahwa kayu yang umumnya berukuran kecil itu biasanya dimanfaatkan tidak lama setelah ditebang. Kemungkinan ini berbeda dengan kayu ulin gelondongan yang besar yang barangkali pemanfaatannya dapat berulang. Misalnya adalah kayu itu telah ditebang lama dan dipergunakan di tempat lain, kemudian digunakan lagi di Situs Patihmuhur. Jika itu yang terjadi, umur yang diperoleh dapat bias. Hal ini disebabkan analisis umur dengan metode radiokarbon diperoleh dari penghitungan pelepasan/peluruhan karbon (Chichagova \& Cherkinsky, 1993) pada saat kayu ditebang, yaitu pada saat kayu tidak lagi menjalani aktivitas hidupnya. Pada saat itulah karbon tertinggal di dalam batang kayu dan itulah umur yang diperoleh. Karena kekhawatiran kayu ulin memungkinkan dipakai ulang, misalnya ditebang jauh sebelum penggunaannya di Situs Patihmuhur, pemilihan terhadap sampel ini dihindari. Sebaliknya, dipilih sampel yang memungkinkan penebangan dan penggunaannya tidak jauh berbeda dari sini waktu. Oleh karena alasan itulah, kayu gelam yang dijadikan sampel dianalisis dengan radiokarbon.

Hasil analisis radiokarbon menunjukkan bahwa umur gelam tersebut adalah $640 \pm 110$ BP (Gambar 7). Hasil itu kemudian dikalibrasi secara daring melalui situs CalPal yang kemudian diperoleh angka tahun $1328 \pm$ 68.A.D. Angka ini menunjukkan rentang tahun 1260-1396 AD (lihat Gambar 8).

Rentang usia ini berkaitan dengan keberlangsungan Kerajaan Negaradaha. Kekuasaan kerajaan itu berakhir ketika muncul pemerintahan baru, yaitu Kerajaan Banjar. Ahmad Suriadi (2014) meyakini bahwa Kerajaan Banjar paling tidak sudah berdiri pada tahun $1526 \mathrm{M}$. Tahun ini diperoleh dari pahatan di pintu Masjid Sultan Suriansyah di Kuin. Diketahui bahwa bangunan itu merupakan masjid pertama yang dibangun oleh Kerajaan Banjar. 
Dengan demikian, Kerajaan Negaradaha harusnya hanya eksis hingga sebelum tahun 1526. Jika hasil analisis radiokarbon menunjukkan rentang waktu usia temuan di Situs Patihmuhur pada tahun 1260-1396 M, hasil itu memungkinkan bahwa temuan di Situs Patihmuhur berkaitan dengan Kerajaan Negaradaha.

Dari indikasi yang disebutkan di atas, penulis bersimpulan bahwa temuantemuan di Situs Patihmuhur merupakan sisa-sisa pelabuhan. Sebagian isi Hikayat Banjarmenyebutbahwa Pangeran Samudra mendayung perahu ke arah hilir hingga ke bandar/pelabuhan, kemudian bersembunyi di Desa Bilandean (seberang Bandar). Nama desa itu sekarang ini masih ada, lokasinya di seberang Situs Patihmuhur. Tampaknya data yang dipaparkan di depan masih relevan bahwa Situs Patihmuhur adalah pelabuhan, seperti halnya yang disebut dalam Hikayat Banjar, tepatnya Pelabuhan Muarabahan.

Pelabuhan ini cukup ramai pada masanya, gambarannya seperti yang disampaikan A.A. Canse, sebagaimana diacu Alfred B. Hudson (1967) yang menyatakan bahwa Kerajaan Negaradaha memindahkan pelabuhan dari Muara Rampiau ke Muarabahan. Disebutkan juga bahwa pelabuhan di Muarabahan lebih ramai dan pedagang yang datang antara lain dari Gujerati, Chinese, Malay, Makasarese, dan Badjau.

Pernyataan itu menegaskan bahwa Pelabuhan Muarabahan atau yang sekarang disebut Situs Patihmuhur memainkan peranan yang penting dalam kegiatan perdagangan. Kegiatan perdagangan itu tidak hanya lokal, tetapi juga antarbangsa. Selain itu, hasil penelitian tentang jaringan maritim Indonesia menyebutkan bahwa
Pulau Kalimantan memiliki peran antara lain melalui jalur transportasi Sungai Kapuas, Katingan, dan Barito (Lapian, 1985). Temuan itu dikuatkan oleh hasil penelitian Sunarningsih di Situs Penggandingan, Kalimantan Selatan, yang berhasil menemukan fragmen keramik China dari Dinasti Yuan (abad 13-14, jumlah temuannya terbanyak dan beberapa keramik lain dari Dinasti Song (abad 1113). Situs Penggandingan berada di tepi Sungai Negara, yang merupakan anak sungai Barito (Sunarningsih, 2013).

Peran sungai dalam jaringan maritim dan temuan keramik China di anak sungainya menunjukkan bahwa Sungai Barito memiliki peran dalam jalur perdagangan internasional. Dengan demikian, situs pelabuhan di Patihmuhur yang berada di tepi Sungai Barito, berada di jalur perdagangan internasional. Dengan posisi yang demikian, Patihmuhur merupakan situs penting yang dapat menjadi monumen sejarah perdagangan dunia yang ada di negara kita.

\section{Nilai Penting Situs Patihmuhur}

Di Indonesia tinggalan pelabuhan dari masa pra-Islam tidak banyak. Pelabuhan dari masa pra-Islam yang sering disebut antara lain Kambang Putih di Tuban, Jawa Timur, yaitu dari masa Kerajaan Majapahit (Khasanah, 2017), pelabuhan Barus yang diduga pernah menjadi bagian dari kekuasaan Kerajaan Sriwijaya dan Pelabuhan Kota Cina di Deli dengan indikasi adanya dua temuan patung dari tokoh Budha dan Hindu (Pradjoko \& Utomo, 2013).

Sementara itu, yang berasal dari Kalimantan diperoleh informasi adanya pelabuhan berdasarkan sumber sejarah (Hikayat Banjar) dan juga hasil analisis 
para ahli. Hasil analisis sebagian ahli menyebutkan bahwa pernah ada pelabuhan (masa pra-Islam), yaitu Muara Rampiau dan Muarabahan (Hudson, 1967). Akan tetapi, pada saat itu hal tersebut belum dibarengi dengan temuan material yang menunjukkan bekas pelabuhan.

Sekarang ini temuan Situs Patihmuhur memberikan harapan itu. Hasil analisis bentuk, fungsi, konteks, dan keruangan menunjukkan bahwa temuan-temuan itu merupakan bekas pelabuhan. Sementara itu, hasil analisis radiokarbon dating menunjukkan umur antara tahun 1260-1396 Masehi. Pada rentang waktu tersebut, di Kalimantan Selatan, berlangsung kekuasaan Kerajaan Negaradaha. Demikian juga dari sumber sejarah (Hikayat Banjar), temuan di Situs Patihmuhur memiliki konteks dengan perjalanan sejarah Kerajaan Negaradaha.

Disebutkan dalam Hikayat Banjar bahwa raja Negaradaha wafat, sedangkan putra mahkota (Raden Samudra) masih berusia remaja. Oleh karena itu, untuk sementara jalannya pemerintahan diserahkan kepada pamannya, yaitu Pangeran Temenggung. Semua itu dilakukan dengan perjanjian, yaitu ketika saatnya tiba, kekuasaan harus dikembalikan kepada Pangeran Samudera. Akan tetapi, yang terjadi justru upaya untuk menyingkirkan putra mahkota. Oleh karena itu, beberapa tokoh yang berada di pihak putra mahkota menyarankan putra mahkota menghindar dan sembunyi di tempat yang aman.

Berkaitan dengan saran itu, Pangeran Samudra mendayung perahu dari hulu menuju ke hilir dan sampailah di Bandar Muarabahan. Namun, Pangeran Samudra bukan bersembunyi di tempat tersebut, melainkan di seberang pelabuhan, yaitu di Desa Bilandean. Selama dalam persembunyian, Pangeran Samudera juga hilir mudik ke arah Banjarmasin. Pada akhirnya ia bertemu dengan Patih Masih dan menyusun kekuatan untuk menyerang pamannya dan mengambil hak atas kekuasaan di Negaradaha.

Cerita ini dapat menginformasikan tentang titik-titik keberadaan Kerajaan Negaradaha, Bandar Muarabahan, Bilandean, dan Banjarmasin. Sebenarnya dari titik-titik yang disebutkan itu juga terdapat dua pelabuhan yang lain, yaitu di Muara Rampiau (Tapin) dan Banjarmasin. Akan tetapi, hingga saat ini pada kedua pelabuhan tersebut belum pernah ditemukan bukti-buktinya. Oleh karena itu, Situs Patihmuhur ini merupakan temuan penting, contoh, dan sebagai satu-satunya situs pelabuhan pra-Islam di Kalimantan.

Tampaknya, nilai penting itu bukan karena menjadi satu-satunya contoh, tetapi juga menjadi bukti bahwa wilayah Nusantara merupakan bagian dari jalur penting pelayaran dan perdagangan dunia. Ketika dunia atau Asia dihubungkan oleh jalur sutra yang antara lain melalui lautan, Situs Patihmuhur telah membuktikan peranan Indonesia sebagai bagian dari jalur pelayaran. Demikian strategisnya Situs Patihmuhur sehingga layak sekali untuk dilestarikan, bahkan dicagarbudayakan. Dengan peranannya yang tidak hanya di tingkat lokal, kajian-kajian yang lebih mendalam akan dapat mengantarkan situs ini menjadi warisan budaya dalam level yang lebih tinggi.

\section{Stategi Pelestarian}

Tampaknya ada tiga hal yang dapat dilakukan untuk melestarikan situs ini, yaitu mempertahankan keberadaan air di situs, mengembalikan tiang-tiang yang 
sudah tercabut, dan merekonstruksikannya dalam bentuk digital. Upaya pertama dilakukan dengan cara mempertahankan air selama mungkin berada di situs.

Diketahui bahwa tiang-tiang ulin tepi Sungai Barito tersebut berada di lahan rawa. Dalam rentang satu tahun areal tersebut lebih banyak tergenang air daripada kering.Areal itu hampir delapan bulan basah, maka pelabuhan dibuat dengan menggunakan kayu ulin yang tahan terendam air. Kayu ulin yang terendam air atau terkubur dalam tanah yang basah tahan dalam puluhan, bahkan ratusan tahun (Hidayat, 2014). Tampaknya alasan itu yang mendorong pembuat pelabuhan memilih kayu ulin sebagai bahannya. Kayu lain yang juga dimanfaatkan sebagai bahan bangunan adalah gelam (Vita, 2016). Jenis kayu ini juga memiliki ketahanan bagus jika ditimbun di dalam tanah yang basah atau rawa (Prayitno \& Marsoem, 2013).

Hal ini terbukti dari temuan di Situs Patihmuhur, kayu-kayu yang digunakan berasal dari kayu ulin dan sebagian kecil kayu gelam.Kedua jenis kayu tersebut ditemukan dalam keadaan masih bagus. Padahal, jika ditinjau dari umurnya yang menunjukkan angka tahun antara 1260-1396 Masehi, temuan itu paling tidak telah berumur 400-800 tahun. Hal itu membuktikan bahwa kayu ulin dan gelam adalah jenis kayu yang paling cocok digunakan di tanah yang basah. Oleh karena itu, pelestariannya dilakukan dengan mempertahankan lahan selalu tergenang. Upaya itu tidak dapat hanya dibiarkan begitu saja, tetapi juga harus dilakukan dengan campur tangan manusia.

Campur tangan yang dimaksud adalah menciptakan kondisi agar memungkinkan genangan air tetap bertahan hampir sepanjang tahun. Jika fakta di lapangan menunjukkan bahwa debit air Sungai Barito turun, yang dapat dilakukan adalah mengangkat air dan mengalirkannya ke situs. Setelah air ada di situs, air harus dapat dipertahankan selama mungkin dan menggenang. Kemungkinan besar yang harus dilakukan adalah membuat pembatas alamiah yang sebenarnya di Situs Patihmuhur yang sekarang ini sudah ada. Batas alamiah itu adalah tanah meninggi yang menghambat keluarnya air dari situs ke sungai.

Walaupun tidak ada jalur air dari sungai ke situs, ketika musim penghujan tiba atau ketika level air Sungai Barito naik, tanah di sekitar sungai akan mengalami intrusi air. Hal ini juga terjadi di Situs Patihmuhur. Namun, drainase tetap diperlukan untuk mengalirkan air ketika banjir di situs. Sebaliknya, pada musim kemarau jalur air harus ditutup untuk menghindari keluarnya air ke sungai. Bahkan, pada musim kemarau perlu dilakukan pengangkatan air dari sungai ke situs untuk mempertahankan kondisi basah situs dan tetap tergenang/ basah.

Selain itu, pelestarian juga dapat dilakukan dengan melakukan pemugaran situs, yaitu mengembalikan tiang-tiang yang sudah tercabut ke posisi asalnya. Jika memperhatikan panjang tiang yang mencapai empat meter, upaya menancapkan kembali tidaklah mudah. Tampaknya hanya alat berat yang dapat menancapkan tiang itu ke tempatnya. Namun, jika memperhatikan kondisi situs yang tanahnya cukup lembek, penggunaan alat berat justru akan merusak situs.

Oleh karena itu, penulis menyarankan bahwa pemugaran cukup dilakukan dengan mengembalikan tiang-tiang dalam ukuran yang tidak terlalu panjang. Dalam hal 
ini yang diperlukan adalah wujud tiangtiang di permukaan tanah telah terpasang. Akan tetapi, posisinya tidak harus sedalam tiang-tiang yang asli.Tujuan yang ingin diraih dari pemugaran tersebut adalah menunjukkan kembali keberadaan tiang. Tiang-tiang yang dikembalikan dalam keadaan tidak utuh seperti aslinyanya perlu diberi tanda untuk membedakan dengan yang asli.

Setelah dilakukan pemugaran, kondisi yang ada di lapangan perlu dipindahkan dalam bentuk digital. Pekerjaan ini dimaksudkan untuk mendokumentasikan situs dan keadaannya. Pendokumentasian ini tidak hanya diperuntukkan sebagai dokumen, tetapi juga dimanfaatkan untuk informasi digital. Dengan demikian, pekerjaan ini mempunyai dua manfaat, yaitu untuk dokumentasi dan untuk tayangan (display). Dua-duanya sangat mendukung kegiatan pelestarian situs.

\section{SIMPULAN}

Berdasarkan uraian di atas, diketahui bahwa pelabuhan di Situs Patihmuhur memiliki peranan yang penting pada masanya. Peranan itu berkaitan dengan kegiatan ekonomi di Kalimantan saat itu dan juga kegiatan perdagangan dunia. Peranan yang seperti ini membuktikan bahwa Situs Patihmuhur memiliki nilai penting yang tinggi. Oleh karena itu, situs ini layak dilestarikan, bahkan dicagarbudayakan. Lebih dari itu, layak diupayakan agar situs ini menjadi salah warisan tingkat nasional, bahkan jika mungkin tingkat dunia. Hal ini dikaitkan dengan bukti jalur perdagangan dunia yang melintas di Indonesia atau mungkin jika bangsa kita lebih dikedepankan sebagai jalur rempah dunia.

Untuk menunjukkan kepada masyarakat akan bukti peranan nenek moyang kita yang diwakili oleh Kerajaan Negaradaha dalam perdagangan dunia, pelabuhan itu harus dipugar. Caranya dengan mengembalikan tiang ke posisi aslinya. Tidak harus tiang dengan panjang yang sama, tetapi paling tidak ujung tiang terlihat di permukaan tanah, sebagaimana dulu sebelum dicabut. Pemugaran juga perlu dilakukan dalam wujud digital agar tersimpan dalam bentuk yang rapi sekaligus dapat diinformasikan kepada masyarakat dalam kemasan yang menarik.

Pelestarian situs harus dilakukan dengan menggunakan cara yang sesuai dengan karakter situsnya. Temuan pelabuhan yang dibuat dengan bahan kayu tersebut berada di lokasi yang selalu tergenang air. Kondisi situs dan bahan untuk membuat pelabuhan telah menunjukkan kepada kita bagaimana kearifan lokal masyarakat saat itu diimplementasikan. Oleh karena itu, kegiatan pelestarian situs tersebut, untuk saat ini, perlu dilakukan dengan meniru kearifan lokal mereka, yaitu mempertahankan genangan air di situs selama mungkin. Pekerjaan itu perlu dilakukan secara alamiah atau dengan campur tangan manusia.

\section{DAFTAR PUSTAKA}

Afni, S. N. (2017). Analisis Penggunaan Beton sebagai Alternatif Pengganti Kayu Ulin pada Jenis Fondasi Tradisional untuk Bangunan di Atas Tanah Lunak di Banjarmasin. Jurnal Teknologi Berkelanjutan, 6(01), 30-38. 
Arikunto, S. (2002). Prosedur Suatu Penelitian: Pendekatan Praktek (Edisi Revisi Kelima Ed.). Jakarta: Rineka Cipta.

Arisanty, D. (2014). Sediment Dynamic in Barito Delta, Southern Kalimantan, Indonesia. Journal of Environments, 1(1), 30-37.

Atmosudiro, S. (1981). Bangunan Megalitik Salah Satu Cerminan Solidaritas Masa Perundagian. Berkala Arkeologi, 2(1), 36-41.

Chichagova,O., \& Cherkinsky, A. (1993). Problems in Radiocarbon Dating of Soils. Radiocarbon, 35(3), 351-362. doi: https://doi.org/10.1017/S0033822200060355

Harto, G. R. (2015). Analisis Erosi dan Sedimentasi Sungai Siak Menggunakan Data Satelit. Jurnal Online Mahasiswa Fakultas Teknik Universitas Riau, 2(2), 1-5.

Hidayat, H. (2014). Konteks Ekologi Kota Tepian Sungai dalam Perspektif Lokalitas Bahan Bangunan. Paper presented at the Architecture Event Membangun Karakter Kota Berbasis Lokalitas.

Hudson, A. B. (1967). The Padju Epat Ma'anjan Dajak in Historical Perspective. Indonesia(4), 8-42. doi: $10.2307 / 3350903$

Idwar, S. (1958). Sedjarah Bandjarmasin. Bandung: KPPK Balai Pendidikan Guru.

Juliansyah, N. (2011). Metodologi Penelitian: Skripsi, Tesis, Disertasi dan Karya Ilmiah. Jakarta: Kencana Prenada Media Group.

Junaidi, F. F. (2014). Analisis Distribusi Kecepatan Aliran Sungai Musi (Ruas Jembatan Ampera Sampai dengan Pulau Kemaro). Jurnal Teknik Sipil dan Lingkungan, 2(3), 542-552.

Khasanah, L. I. (2017). Pelabuhan Kambang Putih pada Masa Majapahit Tahun 1350-1389. Avatara, 5(3), 402-417.

Lapian, A. B. (1985). The Maritime Network in The Indonesian Archipelago in The Fourteenth Century. SPAFA Digest (1980-1990), 6(1), 400-45.

Lipe, W. D. (2009). Archaeological Values and Resource Management. In L. Sebastian \& W. D. Lipe (Eds.), Archaeology and Cultural Resource Management Visions for the Future. Santa Fe: School for Advanced Research Press.

Marzuki, I. W. (2015). Potensi Tinggalan Arkeologis di Kawasan Bandar Udara Sam Ratulangi Manado: Upaya Pelestarian, Pemanfaatan, dan Pengembangan bagi Masyarakat. Kapata Arkeologi, 11(2), 111-122. doi: http://dx.doi.org/10.24832/ kapata.v11i2.291

Mentayani, I. (2008a). Analisis Asal Mula Arsitektur Banjar Studi Kasus: Arsitektur Tradisional Rumah Bubungan Tinggi. Jurnal Teknik Sipil dan Perencanaan, 10(1), 1-12.

Mentayani, I. (2008b). Jejak Hubungan Arsitektur Tradisional Suku Banjar dan Suku Bakumpai. Dimensi Teknik Arsitektur, 36(1), 54-64. doi: https://doi.org/10.9744/ dimensi.36.1.pp.\%2054-64

Mentayani, I., \& Andini, D. N. (2007). Tipologi dan Morfologi Arsitektur Suku Banjar di Kal-Sel. Info-Teknik, 8(2), 114-122.

Novitasari, N. (2016). Kajian Masterplan Drainase Pasang Surut Kota Banjarmasin. Info-Teknik, $9(2), 142-160$.

Pebrianto, A., Rizani, A., Haryanto, R., \& Pratomo, A. (2017). Model Penyulingan Air Bersih di Desa Rangga Surya, Kecamatan Belawang, Kabupaten Barito Kuala Paper presented at the Seminar Nasional ASBIS, Banjarmasin. 
Pertiwi,A.A., Dharmono, D., \& Amintarti, S. (2017). Kemelimpahan Tegakan di Kawasan Bantaran Sungai Barito Desa Simpang Arja Kecamatan Rantau Badauh Kabupaten Barito Kuala. Paper presented at the Seminar Nasional Lahan Basah Potensi, Peluang, dan Tantangan Pengelolaan Lingkungan Lahan Basah Secara Berkelanjutan, Banjarmasin.

Pradjoko, D., \& Utomo, B. B. (2013). Atlas Pelabuhan-Pelabuhan Bersejarah di Indonesia. Jakarta: Direktorat Sejarah dan Nilai Budaya, Direktorat Jenderal Kebudayaan.

Prayitno, T., \& Marsoem, S. (2013). Sifat Fisika-Mekanika Kayu Gelam yang Ditimbun di Rawa Gambut pada Tiga Kelas Diameter. Bionatura-Jurnal Ilmu-ilmu Hayati dan Fisik, 15(3), $165-169$.

Ramadhan, I., Difa Masti, S., Pamungkas, D., \& Setianto, A. (2017, 13-14 September 2017). Analisis terhadap Perubahan Morfologi Sungai Barito sebagai Respons terhadap Tektonik melalui Pengolahan Citra Digital. Paper presented at the Seminar Nasional Kebumian Ke-10, Peran Penelitian Ilmu Kebumian dalam Pembangunan Infrastruktur di Indonesia Yogyakarta, Grha Sabha Pramana.

Ras, J.J. (1968). Hikajat Bandjar: Study in MalayHistoriography. The Hague: Martinus Nijhoff.

Ririmasse, M. N. (2007). Tinjuan Kembali Seni Cadas di Maluku. Kapata Arkeologi, 3(4), 1-21. doi: http://dx.doi.org/10.24832/kapata.v3i4.57.

Soekanto, S., \& Sulistyowati, B. (2012). Sosiologi: Suatu Pengantar (Edisi Revisi). Jakarta: Rajawali Press.

Soekmono, R. (1995). The Javanese Candi: Function and Meaning. Leiden; New York: E.J. Brill.

Sonjaya, J. A. (2005). Pengelolaan Warisan Budaya di Dataran Tinggi Dieng: Kajian Lansekap, Sejarah Pengelolaan, dan Nilai Penting. Universitas Gadjah Mada.

Suhartono, Y. (2008). Pelestarian Sumberdaya Arkeologi dalam Konteks Keruangan di Kawasan Borobudur: Studi Kasus Candi Borobudur, Mendut dan Pawon. Universitas Gadjah Mada.

Sunarningsih, S. (2013). Kerajaan Negara Daha di Tepian Sungai Negara, Kalimantan Selatan. Naditira Widya, 7(2), 85-105. doi: 10.24832/nw.v7i2.94

Suriadi, A. (2014). Syekh Muhammad Arsyad Al-Banjari dalam Dinamika Politik Kerajaan Banjar Abad XIX. Banjarmasin: Pusat Penelitian dan penerbitan LP2M IAIN Antasari.

Sutaba, I. M. (2001). Tahta Batu Prasejarah di Bali: Telaah tentang Bentuk dan Fungsinya. Yogyakarta: Yayasan Mahavhira bekerja sama dengan Yayasan Adikarya IKAPI dan Ford Foundation.

Tjahjono, J. E. (2007). Inventarisasi Endapan Gambut Daerah Barambai dan Sekitarnya Kab. Barito Kuala, Prov. Kalimantan Selatan. Paper presented at the Pemaparan Hasil Kegiatan Lapangan dan Non Lapangan, Kelompok Program Penelitian Energi Fosil.

Vita, V. (2016). Adaptasi Masyarakat Pra-Sriwijaya di Lahan Basah Situs Air Sugihan, Sumatra Selatan. Kalpataru, 25(1), 1-14. doi: http://dx.doi.org/10.24832/kpt.v25i1.79

Wasita, W. (2007). Ekskavasi Permukiman Lahan Basah di Situs Gambut, Kabupaten Banjar dan Patih Muhur, Kabupaten Barito Kuala, Kalimantan Selatan Laporan Penelitian Arkeologi. Banjarbaru: Balai Arkeologi Banjarmasin.

Zain, Z. (2014). Strategi Perlindungan terhadap Arsitektur Tradisional untuk Menjadi Bagian Pelestarian Cagar Budaya Dunia. NALARs, 13(1), 39-50. doi: https://doi.org/10.24853/ nalars. $13.1 . \% 25 \mathrm{p}$ 
- Lampiran

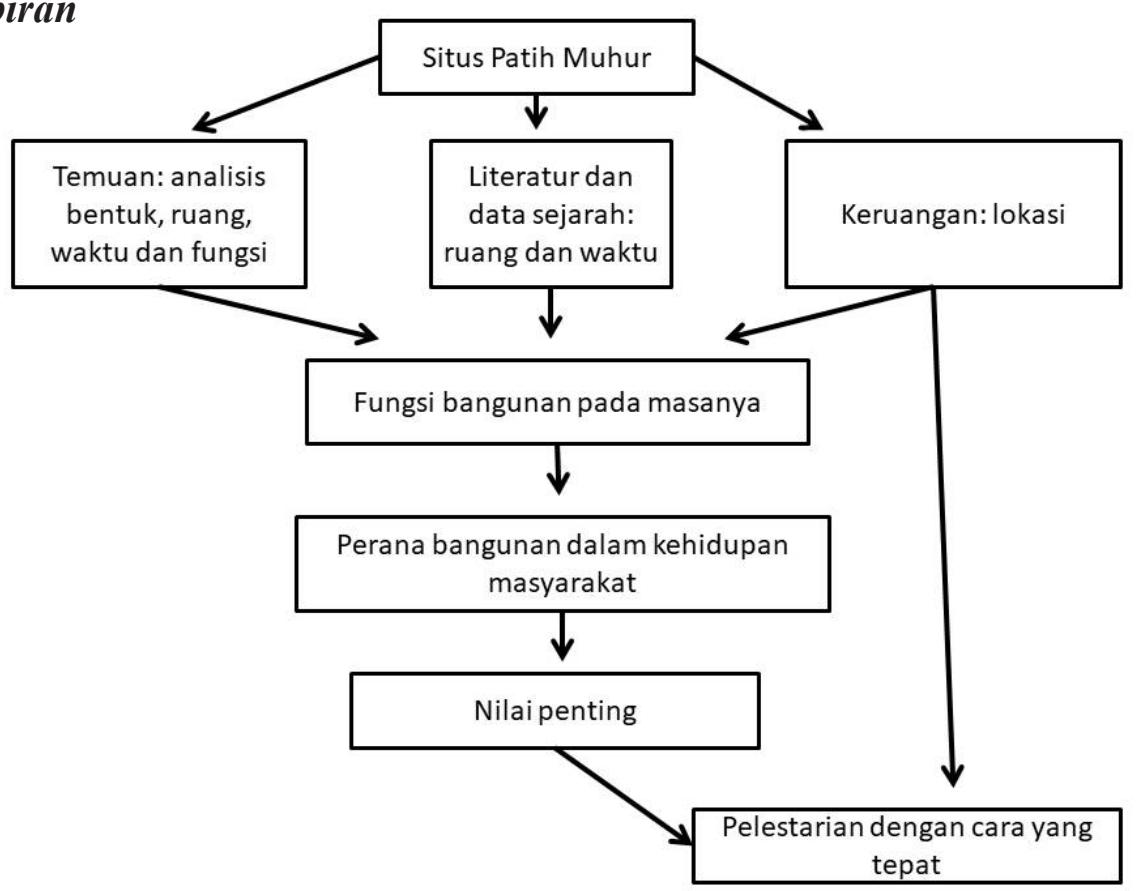

Gambar 1. Alur Pikir dalam Mengungkap Peranan, Nilai Penting, dan Strategi Pelestarian (Sumber: Wasita, 2007).

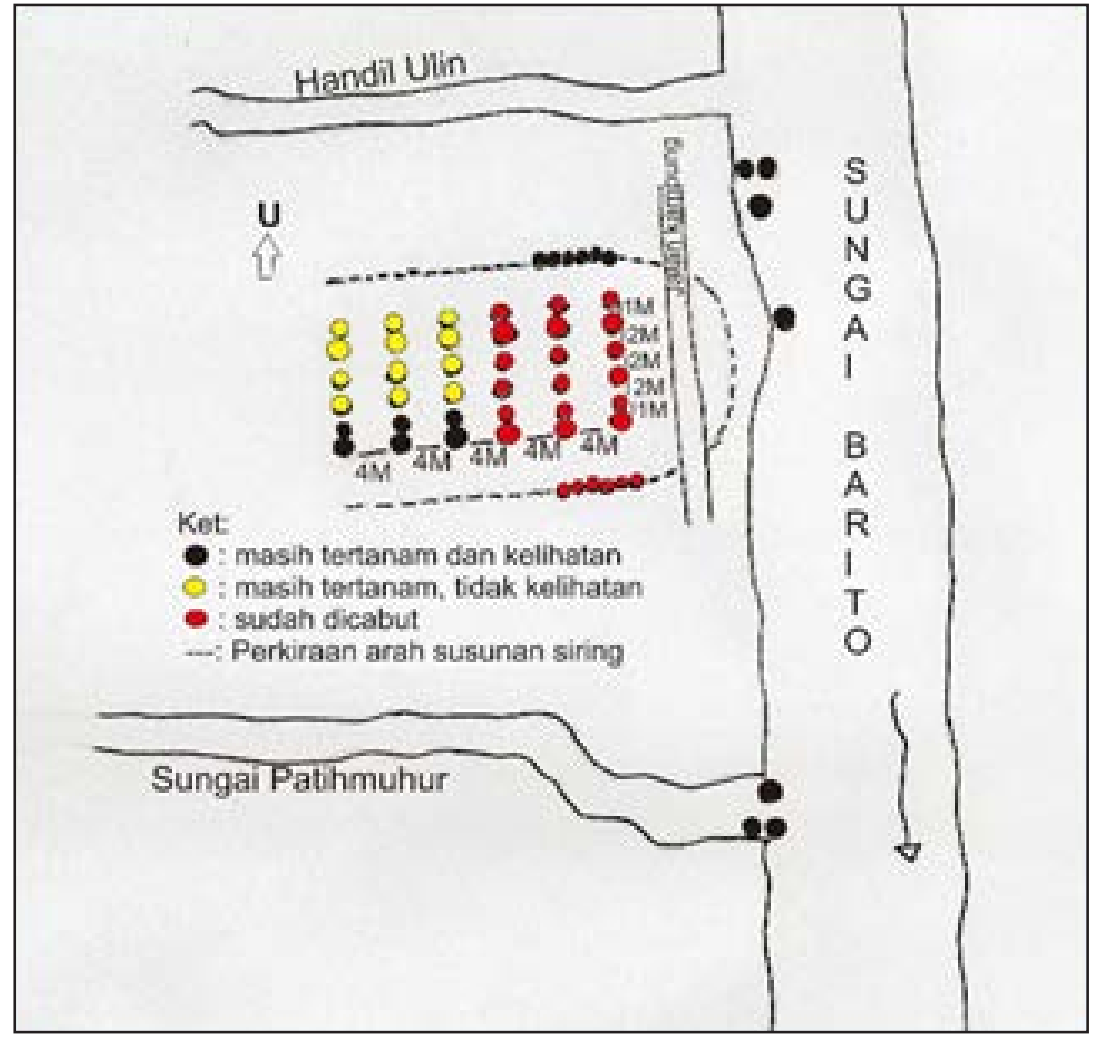

Gambar 2. Sket Tiang-Tiang di Dekat Sungi Barito (Sumber: Wasita, 2007), digambar ulang. 

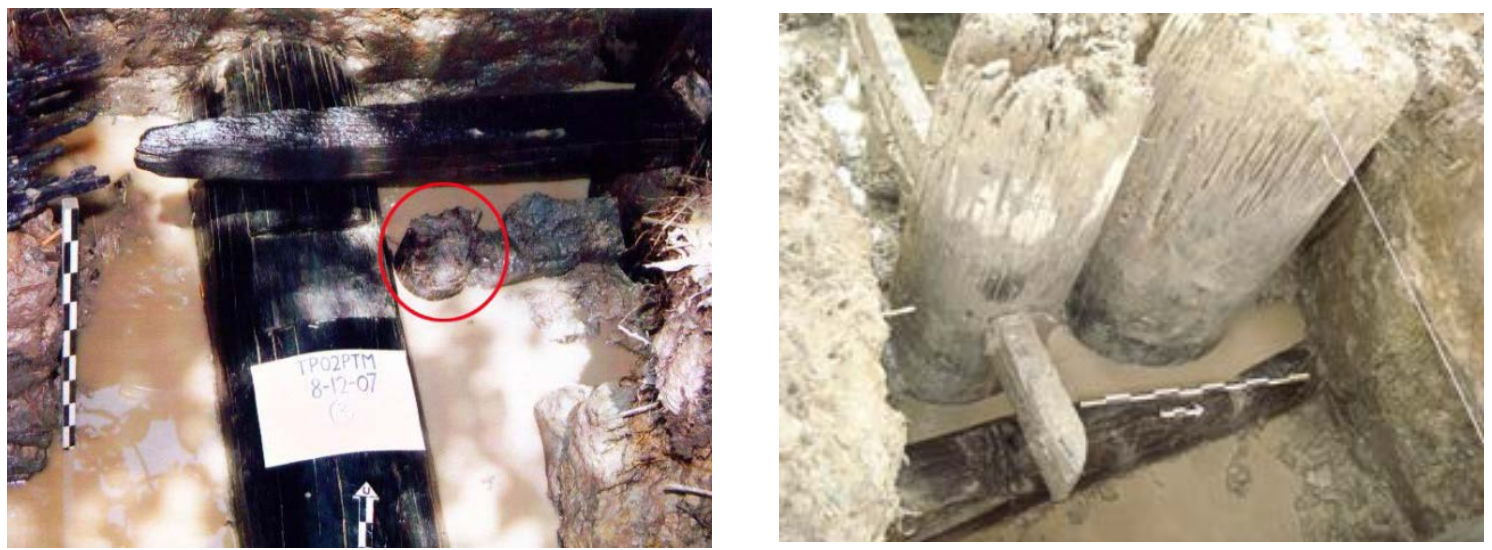

Gambar 3(a) Situasi Tiang pada Kedalaman Sekitar Satu Meter di Bawah Permukaan Tanah, Sisi Kiri (Barat). (b) Sisi Kanan (Timur) (Sumber: Dok.Balar Kalimantan Selatan).

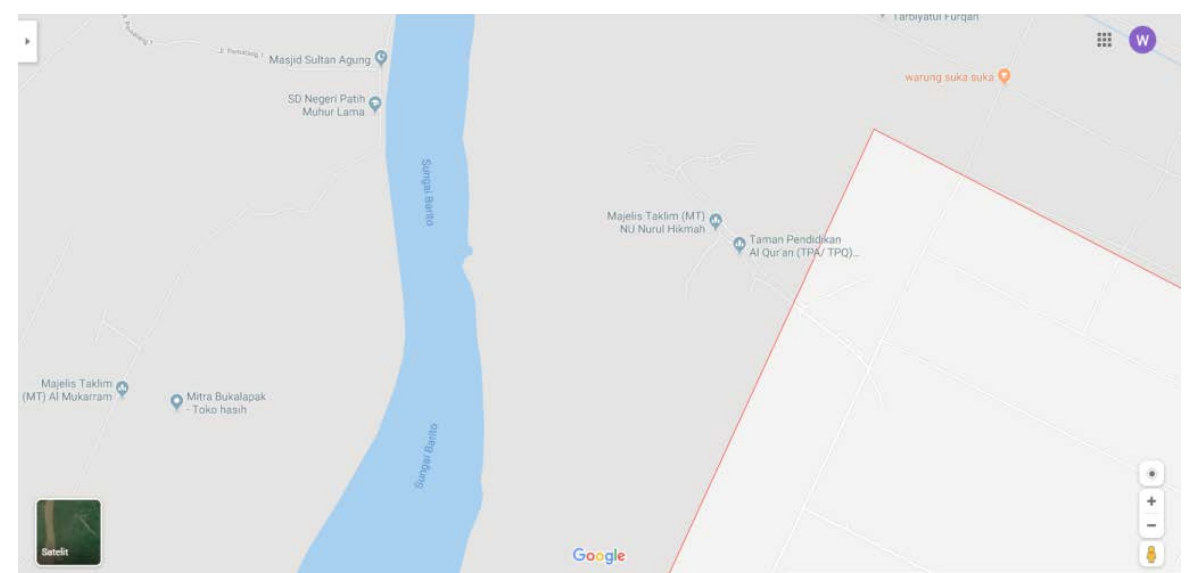

Gambar 4. Posisi Temuan Tiang-Tiang Ulin (di Patihmuhur Lama) dan Desa Belandean (di dalam Kotak Garis Merah) di Kabupaten Barito Kuala (Sumber: Google Maps).

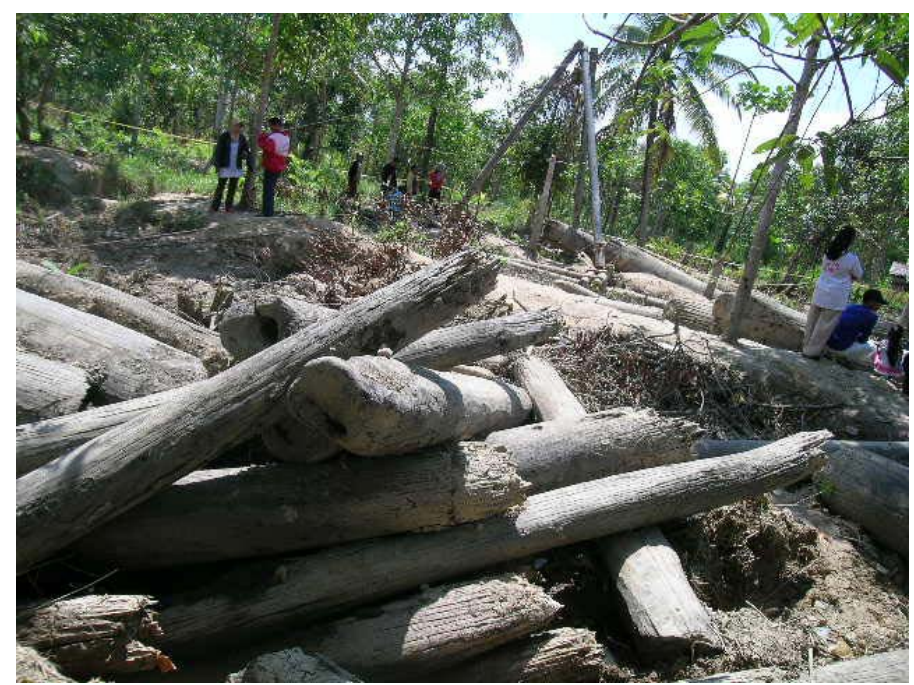

Gambar 5. Tiang-Tiang Kayu yang telah Dicabut dengan Latar Belakang Crane (Sumber: Wasita, 2007). 


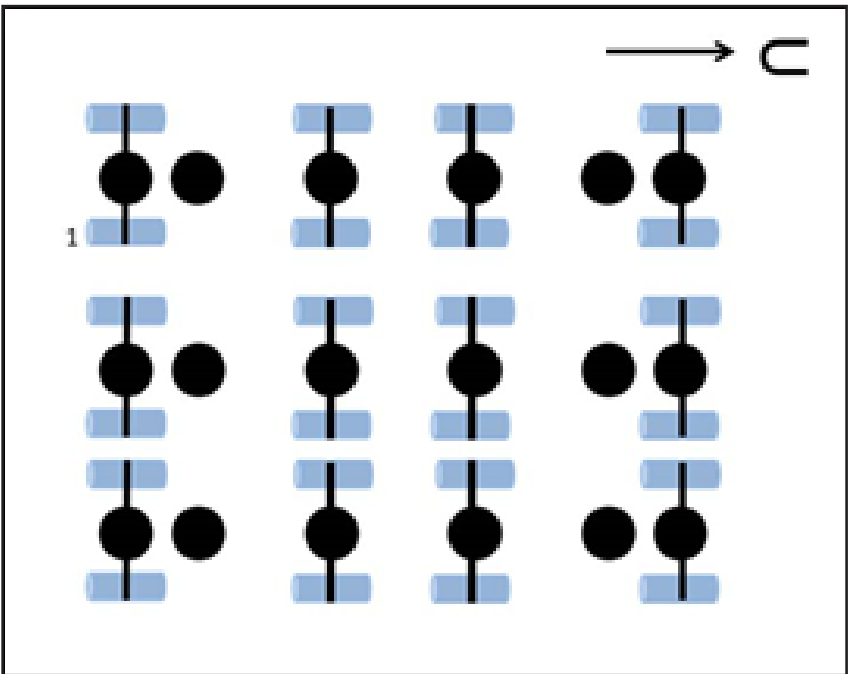

Keterangan:

Gambar 6. Sket Keberadaan Sebagian Kalang Sunduk

tiang, sunduk, dan kalang Nomor 1 kalang dan sunduk terlihat dari hasil penggalian, yang lain dari informasi (Sumber: Wasita, 2007).

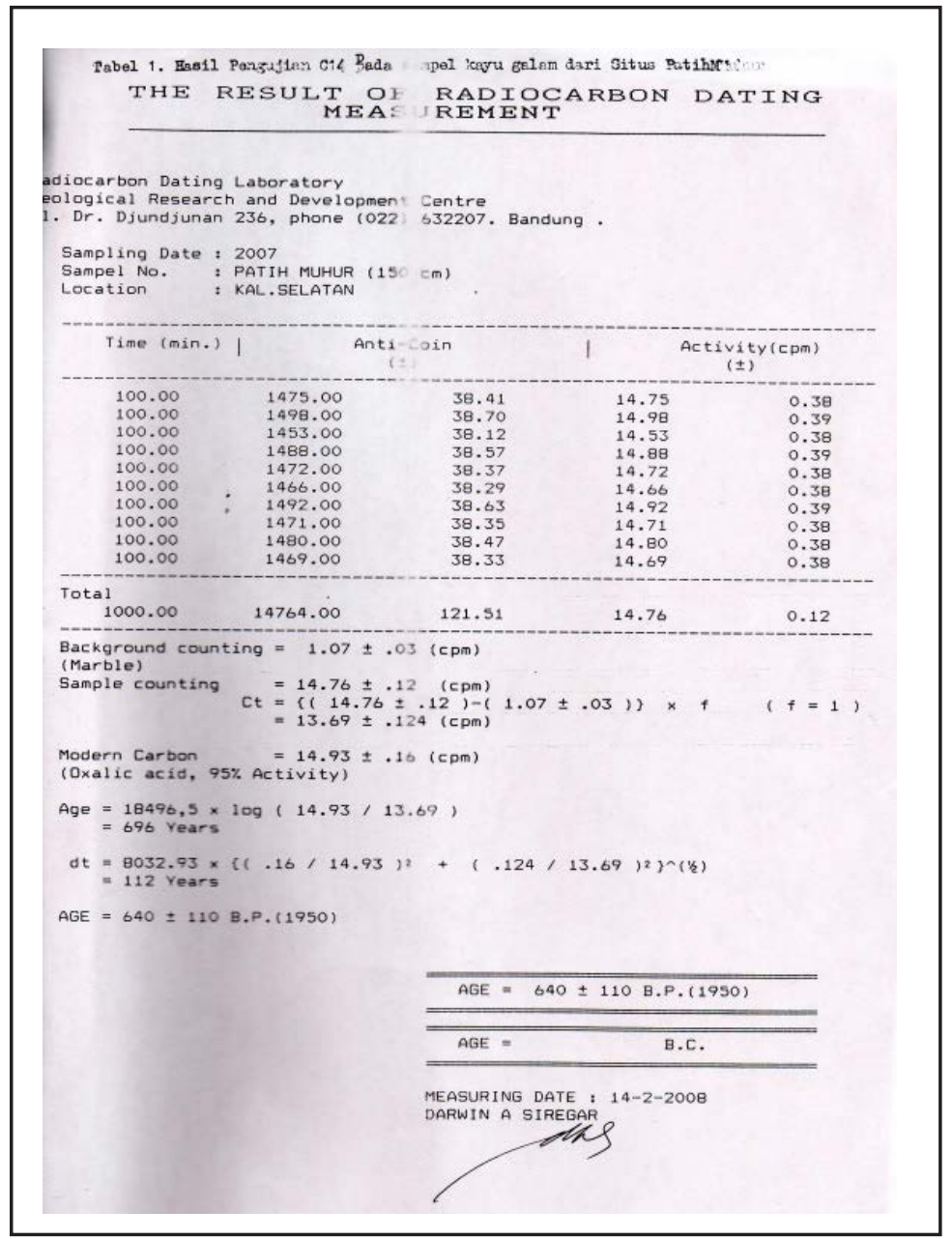

Gambar 7. Hasil Pertanggalan dengan Metode Radiokarbon Dating (Sumber: Wasita, 2007). 


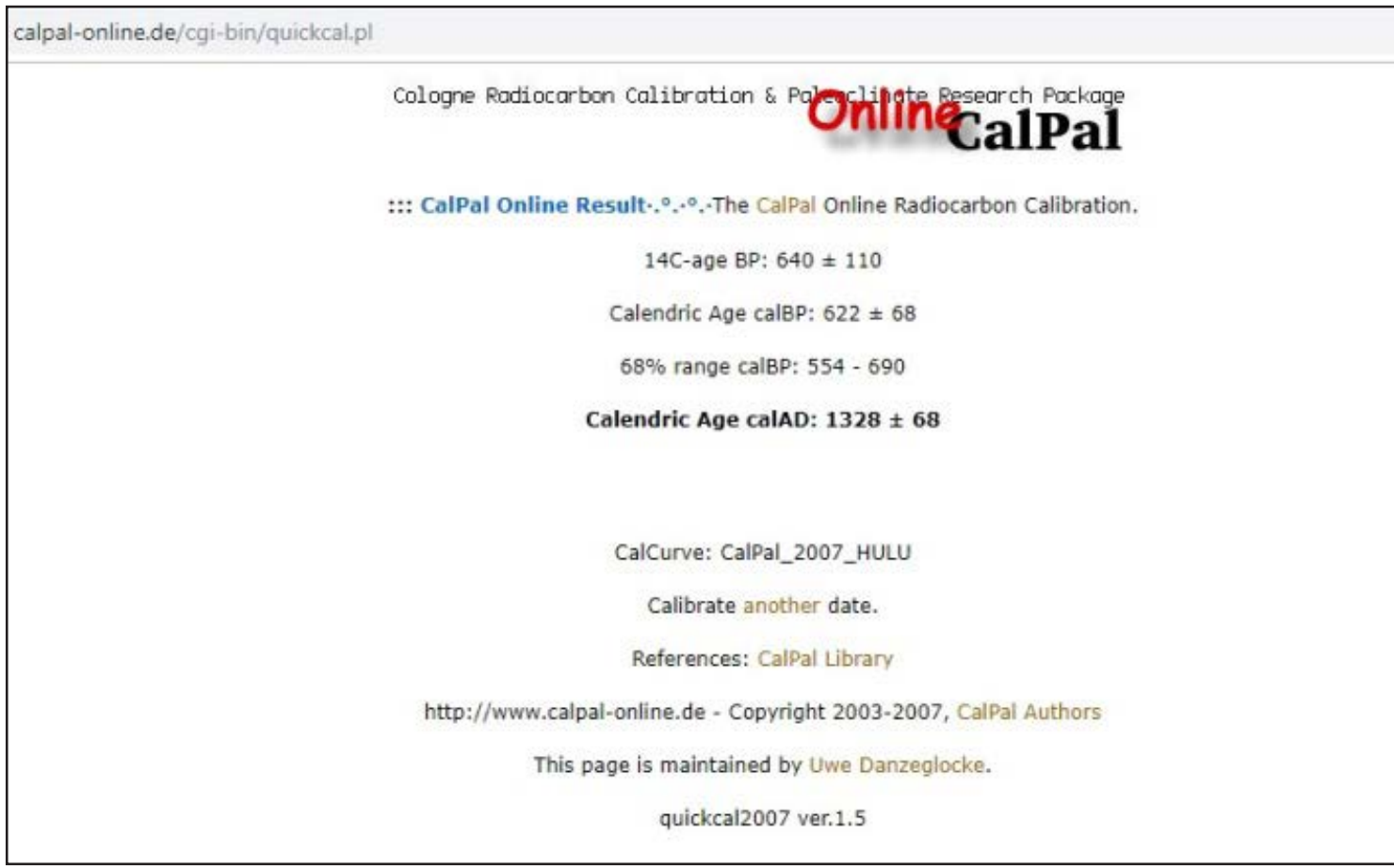

Gambar 8. Hasil Kalibrasi Pertanggalan Situs Patihmuhur. (Sumber: calpal-online.de/cgi-bin/ quickcal.pl) 
PURBaWIDYa $\square$ Vol. 8, No. 2, November 2019 